Maša Kolanović

University of Zagreb

\title{
The Post-Yugoslav “America”: Re-Visiting the United States After the Breakup of Yugoslavia
}

\begin{abstract}
After the breakup of Yugoslavia, the U.S.A. was one of the first and most common destinations for post-Yugoslav dissidents who were critical of the rise of nationalism in the former Yugoslav republics. Prominent post-Yugoslav authors Dubravka Ugrešić and Slavenka Drakulić wrote their first collections of essays (How We Survived Communism and Even Laughed, 1992; Američki fikcionar, 1993) reflecting on turbulent political, cultural and social changes after the breakup of Yugoslavia in which America is very often the place of the subject's distanced position as well as a reference in numerous cultural and political comparisons of capitalism and (post) socialist Europe. The paper examines the role of "America" in their critical views on the breakup of Yugoslavia, looks at how America was shaped as a cultural metaphor and re-viewed as a real environment, and finally how Yugoslav socialist legacy is articulated in their perspective on the United States.
\end{abstract}

Key words: the U.S.A., the breakup of Yugoslavia, capitalism, socialism, Dubravka Ugrešić, Slavenka Drakulić

\section{Pipo's prophecy}

In the cultural texts of the last decade of Yugoslav socialism, also known as the period of decadent socialism, signs of political and economic crisis became more and more visible as the decade was approaching its end. The rise of national particularities together with food, petrol, and electricity shortages were very common motifs of films, books, and popular culture of the period. ${ }^{1}$

1 Since a comprehensive list of examples would be quite long, suffice it to mention Srdan Karanovićs movie Nešto izmedu [Something in between], songs such as Radnička klasa odlazi u raj [The working class goes to heaven] by the Yugoslav new wave band Haustor or 
What reveals itself as symptomatic in the cultural imagery of the Yugoslav crisis of that period is that the motif of the crisis is frequently attached to the motif of leaving for the United States. ${ }^{2}$ In Rajko Grlić's 1984 movie In the Jaws of Life, based on the novel Štefica Cvek u raljama života [Steffie Speck in the Jaws of Life] by Dubravka Ugrešić, a male character named Pipo also seeks his escape from the country in crisis. Throughout the movie, Pipo is struggling with the dilemma of whether to go or not to go to America, which he perceives as a promised land in both the economic and the cultural sense. In a dialogue with his friend Dunja near the end of the movie, while explaining his urge to go to United States, Pipo makes a very significant remark about the current situation in Yugoslavia of the mid-eighties:

Dunja: So, you've decided? You're leaving for America? Pipo: ... Do you know how many people have already left? It will be nasty here, very nasty. For real.

Pipo's comment from today's perspective may sound disturbingly prophetic, knowing the historical facts about the disintegration of Yugoslavia that would follow a few years after the movie was shot. But Pipo eventually decides not to leave Yugoslavia, and the movie has a happy end.

Unlike the movie's happy ending, Dubravka Ugrešić, the author of the novel and the co-author of the movie script found herself in the early 1990s in the middle of the nasty trouble invoked by Pipo. To quote one of her essays

Kataklizma komunizma [The cataclysm of communism] coauthored by the Yugoslav music performers Rambo Amadeus and Riblja Čorba; books such as Sjaj epohe [The shine of the epoch] by Borivoj Radaković, TV shows such as Top lista nadrealista [Top list of surrealists], Bolji život [Better life], etc.

2 For example, in Karanović's movie Marko, an Americanized Yugoslav gigolo wants to leave Yugoslavia, a land in deep crisis, and go to the United States, a country that he perceives as a promised land. Similar examples could be found in the novel Made in U.S.A. by Goran Tribuson or in the popular song Amerika by the Yugoslav new wave band Ekatarina Velika, etc. For more on these particular examples, see Kolanović 2013. 
from the book Americkifikcionar ${ }^{3}$, where the author is writing about her traveling experience to the United States in the early nineties:

The passenger beside me asked in a friendly voice where I was from.

"Yugoslavia," I said.

"Serb or Croat?" he asked, his face showing pride at being in the know...

I looked at my neighbor, I saw he that he was expecting an answer.

"I’m neither," I said. "I don't know who I am."

"Oh, then you're in big trouble," said my neighbor sympathetically. (Ugrešić

28-29)

Ugrešić's essays from this book were first published in Dutch in the newspaper Handelsblad, and in 1993 they were published in Croatian as a book by the publishing house Durieux from Zagreb. It was a book that marked a turning point in the author's writing habitus. ${ }^{4}$ Until the nineties, Ugrešić was well known as a respected author of postmodern fictional works such as the aforementioned Steffie Speck in the Jaws of Life, Lend Me Your Character, and others. Since the collapse of Yugoslavia and the year of political upheaval, 1991, she has mainly published essays focusing on social and cultural problems and the reality of war. This shift from the early nineties, of course, was not only a shift in the thematic-genre level. It was also a step forward from the homogeneous national discourse on the personal and political level. During the war years, this gesture was publicly stigmatized by the then mainstream media and by some prominent Croatian intellectuals, ${ }^{5}$ and her place in the national cultural and literary corpus was perceived as a politically problematic one until early 2000, when some more relevant analyses of her work ap-

3 The book is translated into English under the title Have a Nice Day: From the Balkan War to the American Dream. In the remainder of the article, I will be using the English translation of the book by Celia Hawkesworth published in 1994, although it is slightly modified from the Croatian edition.

4 I deliberately avoid the term "career" here since it has often been abused in discussions of the works of DubravkaUgrešić.

5 Such as Slaven Letica, Antun Šoljan, Viktor Žmegač, and others. See Williams 2013. 
peared in the regional context. ${ }^{6}$ In the period of the early nineties, triggered by the pressures of criticism and threats, Dubravka Ugrešić left the country, deciding not to embrace a newly created national identity and adopting the position of nowhereness. As a writer who travelled around the world, she decided to choose the United States of America as her primary point of comparison to think about the turbulent political situation in former Yugoslavia in her first book of essays published after the breakup of Yugoslavia.

Have a Nice Day is a book about the United States, and at the same time, it is about the war in the former Yugoslavia. In that sense, the hetero-perception of the United States is always followed by the auto-perception of Yugoslavia (and what is left of it). In this article, I will try to rethink the quality of these perceptions, how the experience of the United States has influenced the perception of the Balkan war, and how the experience and specific symbolic "baggage" (or capital) of the former Yugoslavia has influenced the subject's view on the United States. In that book, the United States of America, or simply America- the term more often used by Ugrešić -functions as a deeply culturally rooted metaphor of the West, more a fictional country than a real one. In the early nineties, "America" for the author "seemed about as far away as another planet" (Ugrešić 10); it was the "land on the other side of the looking-glass" (14). What we are dealing with here is thus a discursive image of America where "reception is always a re-projection" (Chew 11). ${ }^{7}$ In reflecting those perceptions rather than judging how false or true they are or of how many stereotypes they consist, I will try to understand their value produced in the specific historical context. In reflecting on the perception of the United States and the war in the former Yugoslavia in this semi-fictional (or semi-factual) book, I will try to explain the complex relationship between

\footnotetext{
6 See, for example, Lukić 2001; Zlatar 2004; Biti 2005, and others.

7 Dubravka Ugrešić as the author is deeply aware of this, and she frequently stresses in the paratextual (Genette 1997) elements of the book, such as the introduction or afterword, her own doubts when she says that any self-respecting writer should especially avoid writing about other countries, explaining that it is "a kind of disguised indecency" that "reduces the irreducible to little dead sheets of paper" (Ugrešić 12).
} 
the author, texts, history, and culture rather than pointing out its so-called misperceptions of the foreign land or the homeland.

\section{Double lenses}

The construction of the perception of "America" and the reflections of political processes in the former Yugoslavia in this book are discursively deeply intertwined. We can speak of some sort of double lenses where the United States and the contemporary situation in the former Yugoslavia are simultaneously reflected. Thus, America and the former Yugoslavia in this book, I might say, together form the shape of a rhizome, to use the term from Gilles Deleuze and Felix Guattari's book A Thousand plateaus: Capitalism and Schizophrenia. As claimed by these two theorists, "any point of a rhizome can be connected to anything other, and must be ... [E]very trait in a rhizome is necessarily linked to a linguistic feature: semiotic chains of every nature are connected to very diverse modes of coding (biological, political, economic, etc.) that bring into play not only different regimes of signs but also states of things of differing status" (Deleuze and Guattari 7). Following further Deleuze and Guattari's concepts, in this particular book of essays, America is re-territorialized with post-Yugoslav signifiers, and the former Yugoslavia is de-territorialized with American signifiers. This discursive strategy produces the effect of the estrangement of both the American and the post-Yugoslav cultural layers of the book.

In the de-territorialization of socialist Yugoslavia in postsocialist times, the main agent of that process is the fictional quality of America. First of all, the subject of these essays cannot escape the fictional influence of America in its own identity, very often reflecting the special cultural and political role which America had in Yugoslavia. As is well known, Yugoslavia after 1948 started to build its own road to communism between the Soviet East and the Capitalist West, dominantly represented by the United States. This specific feature of Yugoslavia as a "somewhat eccentric member of the family of socialist systems" (Hobsbawm 302), was part of Yugoslav recognition in the 
world. ${ }^{8}$ But not just in politics and economy: Yugoslav in-betweenness took a prominent place in the country's self-representations in popular culture.

Particularly interesting in reflecting this Yugoslav feature is Ugrešićs essay titled Yugo Americana, where the author points to the role of America in the building of the Yugoslav geopolitical identity and everyday settings. ${ }^{9}$ America was received in Yugoslav socialism dominantly through fiction and as fiction; it came, as claimed by Ugrešić, "reduced, fragmented, assisted by images from the small and big screens; it came with the media, newspapers, cartoons, music, books, popular culture, symbols, but also with its living media army - returning émigrés, captains of ships, sailors, migrant workers, the children of émigrés. And so it permeated local daily life" (106-7). Though deeply aware of this fictional quality of "America," the subject of these essays cannot escape its performance in its own perception of America in the new post-Yugoslav condition. In that sense, we can speak of a developed Yugo-American cultural intertext (cf. Mathy 3 ) which permeates the threshold of the subject's perception. Combined with the codes of reality of the Balkan war, the fiction of America primarily functions as a symbolic "anesthetic" in working through the subject's trauma of Yugoslavia's demise. But this fictional continuity of "America" is now placed in the broken chain of postsocialist signifiers. That is why the text is full of short circuits (Lodge 239) in which reality meets fiction of postmodern capitalist culture, i.e. America as a land of living postmodernism and the late capitalism meets former Yugoslavia at that time, a land of brutal conflict that overgrows even the most impossible fictional presumptions.

8 This specific feature of Yugoslavia is written about in a CIA document entitled The Yugoslav Experiment in 1967: "Yugoslavia is a Communist state in name and theory, but in practice it is a fully independent state, which has rejected most of the "socialist" experiences of other Communist states, including the USSR. It has deliberately removed a large portion of its economy from direct centralized controls, and despite its retention of a one party political system, it has largely freed its people from arbitrary authority. The Yugoslav experiment appears to be progressing satisfactorily." The Yugoslav Experiment, National Intelligence Estimate, No. 15-67, 13 April 1967.

9 About this feature in Ugrešićs book see also Crnković 2003: 158-59. 
In the mixture of these two elements follows the fictionalization of the war in the former Yugoslavia and the "post-Yugoslavization" of America as a process of their literary estrangement. In such a process, wartime hell and postmodern spectacle meet at one point where the subject of the discourse plays the role of the editor: "Sometimes it seems to me that I have an editing table in my head. I spread out the pictures, correct the spoiled emotional mechanisms. I cut out the shots of the weeping American supermarket contestants and add them to pictures of massacres at home" (Ugrešić 102).In this vicious circuit, we are dealing with multiple semantic turnarounds in the perception of the schizophrenic subject where real is turned into surreal, such as in the example from the essay significantly titled "Shrink":

... I am a divided personality, I see everything in double exposures, I am a house inhabited by parallel worlds, everything exists simultaneously in my head. I look at the American flag and suddenly I seem to see little red sickles and hammers instead of white stars. I look at a television advertisement for necklaces, that's the kind I find most soothing and instead of pearl necklaces for only 65 dollars - I see a slit throat. I walk down Fifth Avenue and suddenly see the buildings falling like card houses ... Everything is mixed up in my head, everything exists simultaneously, nothing has just one meaning and more, nothing is firm any longer, not the earth, not frontiers, not people, not houses ... Everything is so fragile it seems it will shatter any minute ... (55) ${ }^{10}$

The culmination of the subject's constructions is the setting of the Balkan war in the middle of New York. The war, as seen from the top of the Empire State building, is conducted as a plot from Hollywood action movies and video games:

From the Empire State Building, Yugoslavia looks like a children's toy. Brook-

10 As a curiosity, let us mention that this kind of symbolical overlap was also known in the articulation of the author's work during the Yugoslav period, where a hybridity of American and Yugoslav symbols was visually presented in the poster of the movie In the Jaws of Life and the second edition of the novel, Steffie Speck in the Jaws of Life. 
lyn - That's Slovenia. The Brooklyn-Slovenes are diligently setting up their frontiers, their customs posts, bringing in their own money which is no longer called the 'dollar' but the 'tollar.' The Brooklyn-Slovenes are abandoning New York forever. And there are Queens-Serbia and Bronx-Croatia. The Bronx is desperately seeking independence, insisting that it always has been independent of New York. Queens won't let it go, it seems to want to control the whole of New York. The telephone lines between the Bronx and Queens are broken, communications are blocked, the people in the Bronx watch only Bronx-TV, the people in Queens only Queens-TV. And the roads are blocked. You can only get to the Bronx via Boston, and to Queens via Chicago! The New York federal army is on the side of Queens, it's federal, it's army, and it's only natural that it should always want more territory. The Bronx is already half-destroyed, there are a lot of causalities, and the inhabitants of the Bronx are ready to give their lives for the Bronx. And things are hotting up in Manhattan and bubbling in New Jersey ... Whose side will they be on in this war which is creeping through tunnels, which is coming close to the bridges, which is knocking at the doors as well? America watches the New York war calmly, as though it were a video-game. (29-30)

\section{War as capitalism}

The imagined perspective from the Empire State Building highlights the absurdity of the Balkan war from a global perspective, from which the conflicts between the warring ethnic groups can be interpreted as a "narcissism of small differences" (Freud 49). What is interesting about this example, however, is that this schizophrenic construction is not just the result of the subject's experience of the Balkan war, but also from its experience of capitalism in its developed as well as early transitional phase. Though it might seem that this paranoid vision is connecting that which is unconnectable, if we follow Deleuze and Guattari's idea, we see that war and capitalism are in fact deeply interconnected: "the investment of constant capital in equipment, industry, and the war economy, and the investment of variable capital in the population in its physical and mental aspects (both as warmaker and as victim of war)" (421). 
These connections between war and capitalism resonate throughout the text, context, and the habitus of the author in multiple ways. For example, the beginning of the war in the former Yugoslavia was also the beginning of the transition to capitalism. As claimed by Branislav Dimitrijević (2010):

... apart from being an ethnic conflict, the war in Yugoslavia offered the symptomatic model of privatization, of the 'original accumulation of capital' (always achieved through 'resource extraction, conquest and plunder, or enslavement,' as Marx summed it), so this war was the Real of the celebrated capitalist transition in Eastern Europe.

On the other hand, from the perspective of the nationalist transition protagonists, the author herself was often accused of having profited from the war, that the war was a good investment for her, and that she had built her "career" on the ruins of the Balkan war. After all, the scenes of atrocities in New York that are invading the subject's imagination would in 2001, less than 10 years after this text's publication, become real in the terrorist attack on the symbol of capitalism.

\section{Post-Yugoslav eye}

In the overlapping of the perception of socialism, war, and capitalism, signifiers of the United States are thus used to critically estrange the Balkan war, and post-Yugoslav signifiers are used to critically de-familiarize or estrange "America". Thus, strategies of postmodernist ${ }^{11}$ modes of writing used in this book such as contradiction, permutation, discontinuity, randomness, excess, and short circuit (Lodge 220-45), already familiar in the Ugrešić's works published during Yugoslav period, are now shaping post-Yugoslav topics in the jaws of war but also in the jaws of capitalism, inventing simultaneously a post-socialist "America" and postmodernist Balkans. To be even more

11 See also the analysis of this feature of Ugrešićs work by Crnković 2003: 161. 
specific, I would call the cultural perspective of "America" in Ugrešićs book post-Yugoslav because it is shaped from particularly post-Yugoslav cultural codes and it carries the symbolic politics of Yugoslav in-betweenness. Yugoslavia's in-betweenness as a form of rhizome of re-territorialized socialism or de-territorialized capitalism thus discursively reflects on the subject's view of America and the Balkans.

Of course, every exile experience is by default an experience in between, but this one is discursively built from post-Yugoslav cultural codes, carrying the metaphorical, political, and social legacy of socialist Yugoslavia. In this post-Yugoslav social and political perspective, the subject of this book identifies with the economically week and oppressed, such as the homeless, African-Americans, and others in general (Ugrešić 33),but it also negotiates with capitalism, choosing, not without irony, the indulgence of Coca-Cola and American popular culture rather than an essentialist concept of national identity (199) and remaining critical of both sides of Cold-War divisions. ${ }^{12}$ In addition to Ugrešičs view, in this sense I would also like to mention Slavenka Drakulić13 and her essay "Communist Perspective or What I saw in New York?” from her book How We Survived Communism and Even Laughed, in which the capitalist West and the United States are also reflected from a specific cultural and historical perspective.

In that particular essay, Drakulić develops the thesis that, though communism collapsed in Eastern Europe and in building new nation states socialism is being violently removed or re-written in the institutional memory, its citizens still carry a specific social perspective in which they were raised during communism. That specific perspective is reflected in the situations where she notices bread thrown on the floor, uneaten food in garbage cans, or homeless people as she comments:

12 For example, in making critical comparisons between the kitsch of socialist realism, nationalist kitsch, and contemporary American consumer culture (Ugrešić 171).

13 Though they are often mentioned together, there are differences in their esthetic as well as political reflections. 
There is a deeper reason why the poverty sticks to us, why we recognize beggars, homeless people, bumps, petty thieves, drunks, the sick, junkies, why we take it all so personally, why it hurts us. It's because we have a communist eye. Like a third, spiritual eye placed in the middle of one's forehead, this eye scans only a certain type of phenomenon; it is selective for injustice. Even if the socialist states have fallen apart, the ideas of equality and justice haven't. They are still with us, built in like a chip. We remember them from school, from our movies, from literature glorifying the idea of justice, as well as from the clean, beggarless streets of our cities... Transplanted to the United States, we carry that idea and much more with us, like excess baggage that perhaps we would like to drop off or leave at the entrance to this other, promised world. (Drakulić 119-29)

The postsocialist perspective implies that, though socialism is dead, to invoke Jacques Derrida (2006), the specters of Marx are still haunting the perception and imagination of postsocialist Europe. Like Ugrešić, Drakulić also takes the position in between, remaining critical of U.S. capitalism, Eastern Europe's socialism, and specific variations of post-Yugoslav transition. Therefore, I will slightly modify Drakulić's creatively invented term communist eye into postcommunist, postsocialist or, to be more precise, post-Yugoslav eye. The post-Yugoslav perspective, to paraphrase literary critic Robert Rakočević (2011), does not mean "after" but rather "never completely overcoming" the Yugoslav experience; it implies full awareness of the past, but not a fatalistic attachment to it marked by the position of the aforementioned writers and their post-Yugoslav writings. In reflecting on the cultural value of their texts, one must take into account the symbolical legacy of Yugoslavia, or, as Deleuze and Guattari (119) theoretically put it, "To make the distinction between two types of semiotics (for example, the postsignifying regime and the signifying regime), we must consider very diverse domains simultaneously."

In this article I tried to show how this simultaneity functions on the cultural pattern of Ugrešić's essays in multiple ways and how it affects the subject's view of the Balkan war and the United States. This view is in many ways rooted in European intellectual history, which often sees America as a cari- 
cature (Lowell, qtd. in Mathy 1). But stressing its specificity, we can say that with the post-socialist Eastern Europe things are slightly different. Revisting America during the breakup of Yugoslavia for this author also implies re-writing "America" in a post-Yugoslav mode which echoes with the experience of the Yugoslav experiment. As the symbolic child "of Marx and Coca-Cola" (Blazan 205), or "Marx und Markt" (Maleš 1988), this perspective carries the cultural legacy of Yugoslav in-betweenness in its critical reflections on capitalist, socialist, and postsocialist conditions.

\section{Works Cited}

Biti, Vladimir. Doba svjedočenja. Identitet i trauma. Zagreb: Matica hrvatska, 2005. Print. Blazan, Sladja. "Urban Dwellers: Women Writers Who Left Eastern Europe Never to Arrive in the United States." Amerikastudien / American Studies 53.2 (2008): 189-208. Print.

Chew III, William L. "Introduction.” Images of America: Through the European LookingGlass. Ed. Chew. Brussels: VUB P, 1997. 11-23. Print.

Crnković P., Gordana. "Have a Nice Day: From the Balkan War to the American Dream and the Things that Shape the Way We See Each Other." Kazaam! Splat! Ploof! The American Impact on European Popular Culture since 1945. Ed. Sabrina P. Ramet and

Gordana P. Crnković. Lanham, Boulder, New York, Oxford: Rowman \& Littlefield Publishers, 2003. 158-72. Print.

Deleuze, Gilles and Guattari, Felix. Thousand Plateaus: Capitalism and Schizophrenia.

London and Minneapolis: University of Minnesota P, 1988. Print.

Dimitrijević, Branislav. "It is Not Future That Always Comes After” (Some reflections on the project "Political Practices of (Post-) Yugoslav Art"), Red Thread. 2010. Web. 21 Oct. 2015. <http://www.red-thread.org/en/article.asp?a=32>

Drakulić, Slavenka. How We Survived Communism and Even Laughed. London: Vintage, 1993. Print.

Freud, Sigmund. Nelagodnost $u$ kulturi. Rad: Beograd, 1988. Print.

Genette, Gerard. Paratexts: Thresholds of Interpretation. New York, Melbourne, Cambridge: Cambridge UP, 1997. Print. 
Hobsbawm, Eric John Ernest. Doba ekstrema: istorija kratkog dvadesetog veka: 1914-1991. Beograd: Dereta, 2004. Print.

Kolanović, Maša. “Utopija pod upitnikom. Predodžba 'Amerike’ u stihovima dekadentnog socijalizma." Socijalizam na klupi. Jugoslavensko društvo očima nove postjugoslavenske humanistike. Ed. Lada Duraković i Andrea Matošević. Pula, Zagreb: Srednja Europa, Sveučilište Jurja Dobrile u Puli, Sa(n)jam knjige u Istri, 2013. 177-216. Print.

Lodge, David. The Modes of Modern Writing, London: Edward Arnold, 1977. Print. Lukić, Jasmina. “Pisanje kao Antipolitika.” Reč 64 (2001): 73-102. Print.

Maleš, Branko. “Socijalizam je beskrajan.” Polet, April 29, 1988, 3. Print.

Mathy, Jean-Philippe. Extrême-Occident. French Intellectuals and America. Chicago and London: The U of Chicago P, 1993. Print.

Rakočević, Robert. “'Postjugoslovenska književnost'? Ogledala i fantomi.” Sarajevske sveske 35-36, 2011. Web. 15 Sept. 2015. <http://www.sveske.ba/bs/content/postjugoslovenska-knjizevnost-ogledala-i-fantomi>

The Yugoslav Experiment, National Intelligence Estimate, No. 15-67., 13 April 1967.

Web. 15 Sept. 2015. <http://www.foia.cia.gov/sites/default/files/document_ conversions/89801/DOC_0000272967.pdf>

Ugrešić, Dubravka. Have a Nice Day. From the Balkan War to the American Dream. London: Random House, 1994. Print.

Williams, David. Writing Postcommunism: Towards a Literature of the East European Ruins. New York: Palgrave Macmillan, 2013. Print.

Zlatar, Andrea. Tekst, tijelo, trauma. Ogledi o suvremenoj ženskoj književnosti, Zagreb: Naklada Lijevak, 2004. Print. 